\title{
THE BIOLOGICAL MEANING OF ANTI-HBC POSITIVE RESULT IN BLOOD DONORS: RELATION TO HBV-DNA AND TO OTHER SEROLOGICAL MARKERS
}

\author{
Luiz C. ARRAES(1), Ricardo XIMENES(1), Jean-Marie ANDRIEU(2), Wei-LU(2), Silvana BARRETO(3), Leila M.M.B. PEREIRA(1) \& Adauto CASTELO(4)
}

\begin{abstract}
SUMMARY
In order to assess the potential risk of anti-HBc-positive blood donors for post-transfusional hepatitis and to investigate whether other HBV serological markers are capable of identifying the presence of the virus, 1000 first-time blood donors were enrolled between June and July 1997. These donors were screened using routine Brazilian blood center tests (HIV 1 and 2, HTLV 1 and 2, Chagas disease, Syphilis, HCV, HBsAg, anti-HBc and ALT ). The 120 (12\%) found to be anti-HBc-positive underwent further tests: $\mathrm{HBe}$, anti-HBe, anti-HBs and HBV-DNA by PCR. Ten cases were HBsAg positive and all were HBV-DNA positive by PCR. Three HBsAg-negative donors were HBV-DNA-positive. Two HBV-DNA-positive donors were also anti-HBs-positive. All the HBV-positive donors had at least one HBV marker other than anti-HBc.

Anti-HBc is an important cause of blood rejection. Testing for HBsAg alone is not fully protective and anti-HBc remains necessary as a screening test. The presence of anti-HBs is not always indicative of absence of the virus. The addition of other HBV serological markers could represent an alternative in predicting the presence of the virus when compared with PCR. It is recommended that other studies should be carried out to confirm this finding.
\end{abstract}

KEY WORDS: Hepatitis B; Transfusion; Serological markers; HBV-DNA.

\section{INTRODUCTION}

Blood supply is a major concern all over the world. In Brazil, the introduction of Hepatitis B core antibody (anti-HBc) as a surrogate marker for HIV and viral hepatitis in blood transfusion centers has lead to a high donation rejection rate. This rate varies widely over the country, in the Amazonian area as much as $43.7 \%$ being discarded (CLEMENS et al., 2000).

Some studies have been carried out in Brazil with different and, sometimes, contradictory results.

The residual transfusion risk for hepatitis B and C in Santa Catarina (Brazil) has decreased in the 1990's, after the introduction of anti-HBc and anti-HCV in the screening routine (KUPEK, 2001). A recent study shows a high prevalence of anti-HBc (16\%) in blood donors, but no HBV-DNA was detected among them (ALMEIDA NETO et al., 2001). MARTELLI et al. (1999) pointed out that there is not enough evidence to discontinue anti-HBc screening in Brazil.

The significance of anti-HBc in the absence of the surface antigen is somewhat controversial. Such finding could represent 1) a situation where despite anti-HBs and anti-HBe being undetectable, the patient is immunized; 2) a case where HBsAg levels are very low to be detected with routine assays; 3 ) false-positivity or cross-reactivity of anti-HBc; and 4) an immunological window period, in which HBsAg is already undetectable and the surface antibody is not yet detectable (KLEINMAN et al., 1997). In the first three situations no conclusion can be drawn concerning the presence or absence of $\mathrm{HBV}$ without referring to molecular biology methods (BONINO et al., 1981).

Molecular methods have demonstrated the presence of the virus in patients with anti-HBc alone with a frequency varying from 0 to $90 \%$ (LUO et al., 1991; SHIH et al., 1990; WANG et al., 1991). In Brazil, HBV-DNA positivity ranges from $0.8 \%$ among blood donors to $23.4 \%$ among individuals attending outpatient clinics in the state of São Paulo (SUCUPIRA, 1997; CRUZ, 1997). Such wide discrepancy, not completely understood, could result from virological, immunological, or methodological factors, besides region HBV endemicity.

In Northeast Brazil, the high prevalence of anti-HBc-positive blood donors has resulted in a very high level of donation rejection, with obvious consequences in the setting of blood scarcity, and very high costs. On the other hand, with the serological markers used in Brazilian blood transfusion centers, one could not assure the safety of a blood transfusion from anti-HBc-positive donor. 


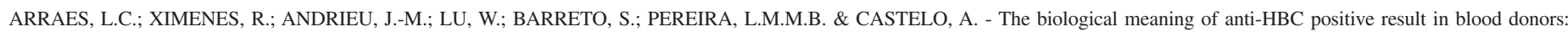
relation to HBV-DNA and to other serological markers. Rev. Inst. Med. trop. S. Paulo, 45(3):137-140, 2003.

The main objective of this study was to assess how frequent is the detection of HBV-DNA among blood donors with normal ALT levels and with negative test results for all safety markers routinely used in Brazilian transfusion centers (syphilis, Chagas disease, HIV, HTLV I/II, $\mathrm{HBsAg}$ and $\mathrm{HCV}$ ) but anti-HBc.

\section{MATERIAL AND METHODS}

Study population: Between June and July 1997, 1000 first time blood donors at the City of Recife (Northeast of Brazil) blood transfusion center were ascertained in a cross-sectional study. Among donors, the frequency of anti-HBc-positive was calculated and its concomitance with HBV-DNA investigated.

Furthermore, among these anti-HBc-positive individuals, it was determined whether other HBV serological markers, not routinely used in Brazilian transfusion centers (anti-HBs, anti-HBe, HBe), could be safely used as surrogate markers to predict the presence of HBV-DNA.

Data Collection: For each participant in the study, the following data were obtained: 1) gender, age, schooling and donation model; 2) history of jaundice or hepatitis, sexual habits, arterial hypertension or hypotension, medication in use, recent alcohol intake, body mass index, symptoms and signals suggesting Dengue Fever or anaemia and skin lesions.

According to these latter variables, the donor was included in or excluded from the study. From the donors included, three samples were collected, two for routine blood transfusion center screening tests and one for centrifugation and freezing at $-22^{\circ} \mathrm{C}$. In this last group, when the sample was positive for anti-HBc, serological markers not routinely used (anti-HBe, anti-HBs and $\mathrm{HBeAg}$ ) and a PCR for HBV-DNA were performed.

Prior to inclusion standard written informed consent was obtained from all participants and the study was approved by the Ethics Committee of HEMOPE (Hemocentro de Pernambuco).

Laboratory Studies: The samples were tested in accordance to the Brazilian Health Ministry recommendations for blood transfusion centers. One thousand samples were tested for Chagas Disease, HCV, HBV (HBsAg and anti-HBc), HIV 1 and 2, HTLV 1 and 2, and syphilis (VDRL).

The first 660 samples were tested for these infections using ELISA methodology (ORGANON). The last 334 samples were tested using chemoluminescense methodology (ABBOTT), with the exception of Chagas Disease testing which was performed using ELISA methods (ABBOTT). Non-routine HBV serological tests were performed on the anti-HBc positive samples as follows: anti-HBs (ELISA, SANOFIPASTEUR), HBe and anti-HBe (Microparticle Enzyme Immunoassay ABBOTT). In the anti-HBC-positive samples, HBV-DNA PCR tests were performed using the Multiple Primers Induced Overlapping Amplification Assay (MUPROVAMA) as described (LU et al., 1999).

Anti-HBc positive samples were tested for PCR and for $\mathrm{HBeAg}$, anti-HBe and anti-HBs.

\section{RESULTS}

Among the 1000 blood donors, there were 120 anti-HBc-positive (12\%). Three samples were lost and could not, for that reason, be tested for non routine tests, i.e., $\mathrm{HBeAg}$, anti-HBe and anti-HBs remaining 117 anti-HBC positive patients. Male and less educated blood donors were the great majority. Some characteristics of the serologic profile of the 117 anti-HBc positive donors are shown on Table 1.

Table 1

Comparison between results of serological markers for hepatitis B virus and PCR in individuals anti-HBc positive at Recife Blood Transfusion Center in 1997

\begin{tabular}{ccccccc}
\hline \multirow{2}{*}{ PCR } & \multicolumn{2}{c}{ HBsAg } & \multicolumn{2}{c}{ Anti-HBs } & \multicolumn{2}{c}{ Markers* } \\
& $(-)$ & $(+)$ & $(-)$ & $(+)$ & $(-)$ & $(+)$ \\
\hline \multirow{2}{*}{$(+)$} & 10 & 3 & 2 & 11 & 13 & 0 \\
& $76.9 \%$ & $23.1 \%$ & $15.4 \%$ & $84.6 \%$ & $100 \%$ & $0 \%$ \\
& 0 & 107 & 73 & 31 & 84 & 20 \\
$(-)$ & $0 \%$ & $100 \%$ & $70.2 \%$ & $29.8 \%$ & $80.8 \%$ & $19.2 \%$ \\
\hline
\end{tabular}

From: HEMOPE; *The presence of at least one of the following serologic markers: HBsAg, anti-HBs, $\mathrm{HBeAg}$, anti-HBe.

Among the 120 anti-HBc-positive blood donors, 13 were HBV-DNA positive, including $10 \mathrm{HBsAg}$ positive and three $\mathrm{HBsAg}$ negative, showing the infectivity of three HBsAg-negative donors.

All the $10 \mathrm{HBsAg}$-positive donors were anti-HBs-negative and HBVDNA-positive. However, two anti-HBs-positive donors were also HBVDNA-positive, indicating that the protective effect of this antibody was not always present.

Performing non-routine blood transfusion center HBV tests in all 120 anti-HBc positive blood donors, it was found that all $13 \mathrm{HBV}-\mathrm{DNA}$ positive donors were also positive for at least another HBV marker (either $\mathrm{HBsAg}$, or anti-HBs, or HBeAg, or anti-HBe). Ten among them were already known as HBsAg positive by tests performed during the serological routine screening. Three HBsAg negative and HBV-DNA positive blood donors were not only anti-HBc positive. Two of them were anti-HBs positive and one was anti-HBe positive. There was no case of anti-HBc positive who was also HBV-DNA-positive without another positive serological test. Eighty-four HBV-DNA-negative donors displayed at least another HBV marker and among 20 HBV-DNAnegative donors, all $\mathrm{HBV}$ markers but anti-HBc, were negative.

\section{DISCUSSION}

This study showed insufficient effectiveness of HBsAg screening for protecting blood recipients from $\mathrm{HBV}$ infection. Three HBsAgnegative blood donors were HBV-DNA-positive and if it were not for the screening of anti-HBc recipients would have been infected. These findings have been broadly supported by previous studies (CARLONI et al., 1986; LEON et al., 1999). On the other hand, in our study detection of anti-HBs did not rule out presence of the virus. 


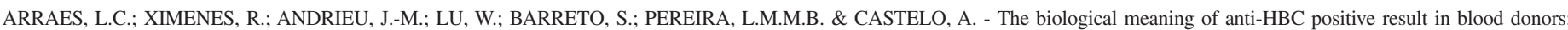
relation to HBV-DNA and to other serological markers. Rev. Inst. Med. trop. S. Paulo, 45(3):137-140, 2003.

Anti-HBs, as a marker of recovery from $\mathrm{HBV}$ infection and protective immunity, is generally believed to be so strong that COELHO \& NOGUEIRA (1995) claimed that it would be safe to release anti-HBc and anti-HBs-positive blood donations. However, in this study, two antiHBs-positive donors were also HBV-DNA-positive. This apparent paradoxical immuno-virological pattern might be due to the presence of HBV quasi-species, often responsible for unusual serological patterns (BLUM, 1993). It did not seem to be the case in this study. The surface genes of samples from the two unusual cases were sequenced and revealed genotype F (common in South America) and genotype A (common in Europe). No mutations that would account for the failure of surface antigen detection was found (TONG, 2001). If the absence of HBsAg does not always indicate the absence of the virus and anti-HBs seropositivity does not always indicate its presence, one could conclude that relying entirely on the serological pattern to rule in or out the virus might be risky.

This phenomenon could be ascribed to limitations of the screening test in terms of specificity and sensibility, to an as yet incomplete knowledge of HBV pathogenesis, or to its wide genetic variation (HARRISSON, 1996). In anti-HBs positive subjects it has been claimed that the virus is totally cleared by both cellular and humoral immunity. Of interest, not a single HBV-DNA-positive case was solely anti-HBcpositive.

Our study offers strong support to the maintenance of anti-HBc, in order to minimize the chances of post-transfusion HBV infection. However, the introduction of other HBV markers in blood transfusion centers should be considered as an alternative to reducing the possible excessive disposal of blood bags in Brazilian blood banks, possibly due to a great quantity of false-positive results. In this study no solely antiHBc-positive blood donor was HBV-positive when assessed by HBVDNA PCR. All HBV PCR positive blood donors were positive also to at least another HBV serological marker.

In conclusion, this study offers some evidence that the presence of two HBV serologic markers may be an indication of a positive $\mathrm{HBV}$ PCR. Nonetheless, larger studies are warranted including individuals from different groups, mainly subjects who are HBV PCR negative, together with patients with positive seromarkers, and the PCR and antiHBs positive subjects before defining new strategies for blood transfusion safety policies based on these findings.

\section{RESUMO}

\section{Significado biológico do resultado anti-HBc positivo em doadores de sangue: relação com HBV-DNA e outros marcadores sorológicos}

Para verificar o risco potencial para hepatite viral pós-transfusional de doadores anti-HBc positivos e investigar se outros marcadores sorológicos do HBV poderiam identificar a presença ou não do vírus, mil doadores de primeira vez foram recrutados entre junho e julho de 1997. Estes doadores foram testados para os testes de rotina utilizados em centros de transfusão brasileiros. Cento e vinte desses doadores foram anti-HBc positivos (12\%). Nestes foram realizados os testes HbeAg, anti-HBc, anti-HBs e a pesquisa do HBV-DNA por PCR.
Dez eram HbsAg positivos, todos com presença do HBV-DNA demonstrada por PCR. Três doadores HbsAg negativos foram HBVDNA positivos.

Dois doadores HBV-DNA positivos também o foram para o antiHBs. Todos os doadores HBV positivos apresentavam pelo menos outro marcador sorológico do $\mathrm{HBV}$, além do anti-HBc.

$\mathrm{O}$ anti-HBc é uma importante causa de descarte de sangue. A pesquisa isolada do HbsAg não é completamente protetora e a presença do anti$\mathrm{HBc}$ permanece necessária como teste de triagem.

A presença do anti-HBs não é sempre indicativa da ausência do vírus.

A adição de outros marcadores pode ser uma alternativa para predizer a presnça do vírus quando comparada com a PCR. Outros estudos, no entanto, devem ser conduzidos para confirmar este achado.

\section{REFERENCES}

1. ALMEIDA NETO, C.; STRAUSS, E.; SABINO, E.C.; SUCUPIRA, M.C.A. \& CHAMONE, D. - Significance of isolated hepatitis B core antibody in blood donors from São Paulo. Rev. Inst. Med. trop. S. Paulo, 43: 203-208, 2001.

2. BLUM, H.E. - Hepatitis B virus: significance of naturally occurring mutants. Intervirology, 35: 40-50, 1993.

3. BONINO, F.; HOYER, B.; NELSON, J. et al. - Hepatitis B virus DNA in the sera of HbsAg carriers: a marker of active hepatitis B virus replication in the liver. Hepatology, 1: $386-391,1981$

4. CARLONI, G.; DELFINI, C.; COLLOCA, S. et al. - Incidence of hepatitis B virus DNA and DNA-polymerase in sera of Italian asymptomatic carriers with the serological markers of HBV. Arch. Virol., 87: 97-105, 1986.

5. CLEMENS, S.A.; FONSECA, J.C.; AZEVEDO, T. et al. - Soroprevalência para hepatite A e B em quatro centros no Brasil. Rev. Soc. bras. Med. trop., 33: 1-10, 2000.

6. COELHO, H.S.M. \& NOGUEIRA, C.M. - Hepatite pós-transfusional e a política doação de sangue no Brasil. GED, 14: 69-71, 1995.

7. CRUZ, C.F.N. - Estudo de doadores de sangue com a presença do anticorpo antiHBc sérico como marcador isolado de infecção pelo vírus da hepatite B. São Paulo, 1997. (PhD dissertation - Escola Paulista de Medicina/Universidade Federal de São Paulo).

8. HARRISON, T.J. - Genetic variation in hepatitis B virus. Europ. J. Gastroent. Hepat., 8: $306-311,1996$

9. KLEINMAN, S.; BUSCH, M.P.; KORELITZ, J.J. \& SCHREIBER, G.B. - The incidence window period model and its use to assess the risk of transfusion-transmitted human immunodeficiency virus and hepatitis $C$ virus infection. Transfus. Med. Rev., 11: 155-157, 1997.

10. KUPEK, E.J. - Residual transfusion risk for hepatitis B and C in Southern Brazil, 199199. J. virol. Hepat., 8: 78-82, 2001.

11. LEON, G.; LOPEZ, J.L.; MAIO, A.; GARCIA, L. \& QUIROZ, A.M. - Investigation of HBV-DNA using the polymerase chain reaction (PCR) in HbsAg negative, anti-HBc positive Venezuelan donors. Sangre (Barcelona), 44: 342-346, 1999.

12. LU, W.; CAO, L.; TY, L.; ARLIE, M. \& ANDRIEU, J.M. - Equivalent amplification of intrinsically variable nucleic acid sequences by multiple-primer-induced overlapping amplification assay: applications for universal detection and quantitation. Nature Med., 5: 1081-1085, 1999. 
ARRAES, L.C.; XIMENES, R.; ANDRIEU, J.-M.; LU, W.; BARRETO, S.; PEREIRA, L.M.M.B. \& CASTELO, A. - The biological meaning of anti-HBC positive result in blood donors: relation to HBV-DNA and to other serological markers. Rev. Inst. Med. trop. S. Paulo, 45(3):137-140, 2003.

13. LUO, K.X.; ZHOU, R.; HE, C.; LIANG, Z.S. \& JIANG, S.B. - Hepatitis B virus DNA in sera of virus carriers positive exclusively for antibodies to the hepatitis B core antigen. J. med. Virol., 35: 55-59, 1991.

14. MARTELLI, C.M.; TURCHI, M.; SOUTO, F.J. et al. - Anti-HBc testing for blood donations in areas with intermediate hepatitis B endemicity. Rev. panamer. Salud públ., 6: 69-73, 1999.

15. SHIH, L.N.; SHEU, J.C.; WANG, J.T. et al. - Serum hepatitis B virus DNA in healthy HbsAg-negative Chinese adults evaluated by polymerase chain reaction. J. med. Virol., 32: 257-260, 1990.
16. SUCUPIRA, M.C.A. - Prevalência do DNA do HBV em amostras de doadores de sangue com AgHBs negativo e anti-HBc positivo. São Paulo, 1997. (Master's thesis - Instituto de Ciências Biomédicas da Universidade de São Paulo).

17. TONG, W. St Thomas Hospital, London. (Personnal communication, 2001).

18. WANG, J.T.; WANG, T.H.; SHEU, J.C. et al. - Detection of hepatitis B virus DNA by polymerase chain reaction in plasma of volunteer blood donors negative for hepatitis B surface antigen. J. infect. Dis., 163: 397-399, 1991.

Received: 18 April 2002

Accepted: 16 May 2003 